\title{
Precocious flowering of plants resulting from in vitro germination of Cycnoches haagii seeds on mycorrhizal fungi presence ${ }^{1}$
}

\author{
Mateus de Aguiar Torrezan², Manoela Aparecida Vieira da Silva², \\ Vespasiano Borges de Paiva Neto ${ }^{3}$, Daly Roxana Castro Padilha ${ }^{2}$, Alana Juliete da Silva Santos ${ }^{3}$
}

\section{ABSTRACT}

Cycnoches haagii is an epiphytic Orchidaceae found in the Brazilian Savannah that presents a great ornamental potential. Aiming at developing a complete seminal propagation protocol of $C$. haagii, as well as testing the influence of the mycorrhizal fungi presence in the process, mature seeds were germinated in vitro in the presence or absence of two fungal isolates, both belonging to the Tulasnella genus ( $\mathrm{FCH}$ and $\mathrm{FHC} 3 \mathrm{E})$, in three culture media (B\&G, Knudson and OMA). The percentage of germinated seeds was evaluated, and the protocorms of the four media with higher percentages were transferred to a new media, aiming at the conversion into plantlets. The seedlings were evaluated for shoot length, number of leaves, length of the largest root, number of roots and total fresh matter. The $\mathrm{B} \& \mathrm{G}$ medium provided a germination rate higher than $60 \%$, besides a higher seedling growth, contributing to $100 \%$ of survival in the acclimatization stage, independently of the mycorrhizal fungi presence. However, only the seedlings from the B\&G medium inoculated with the isolated FHC presented a fast growth when acclimatized, and flowering at the end of the first year of acclimatization. Therefore, the presence of the mycorrhizal fungus FHC on the B\&G medium, during the germination phase, is adequate for the propagation of $C$. haagii, because it accelerates its development and anticipates the ex vitro flowering.

KEYWORDS: Orchid; acclimatization; symbiosis.

\section{INTRODUCTION}

Orchidaceae is one of the largest plant families and contains more than 25,000 species in the entire world (Chase et al. 2015); nevertheless, it is also among the most threatened of all flowering plants (Huang et al. 2018).

\section{RESUMO}

Florescimento precoce de plantas oriundas de sementes de Cycnoches haagii germinadas in vitro na presença de fungos micorrízicos

Cycnoches haagii é uma Orchidaceae epífita encontrada no Cerrado brasileiro, que possui grande potencial ornamental. Objetivando desenvolver um protocolo completo de propagação seminal de $C$. haagii, bem como testar a influência da presença de fungos micorrízicos no processo, sementes maduras foram germinadas in vitro na presença ou ausência de dois isolados fúngicos do gênero Tulasnella (FCH e FHC3E), em três meios de cultura (B\&G, Knudson e OMA). Avaliou-se a porcentagem de sementes germinadas, e os protocormos dos quatro meios com maiores porcentagens foram transferidos para meios novos, visando à conversão em plântulas. As plântulas foram avaliadas quanto ao comprimento da parte aérea, número de folhas, comprimento da maior raiz, número de raízes e massa fresca total. O meio B\&G proporcionou germinação superior a $60 \%$ e maior crescimento das plântulas, contribuindo para $100 \%$ de sobrevivência na fase de aclimatização, independentemente da presença de fungos micorrízicos. No entanto, apenas plântulas oriundas do meio $\mathrm{B} \& \mathrm{G}$ inoculadas com o isolado $\mathrm{FCH}$ apresentaram desenvolvimento acelerado quando aclimatizadas, e floresceram ao final do primeiro ano de aclimatização. Assim, a presença do fungo micorrízico $\mathrm{FCH}$ no meio $\mathrm{B} \& \mathrm{G}$, durante a fase de germinação, é adequado para a propagação de $C$. haagii, pois acelera o desenvolvimento e antecipa a floração ex vitro.

PALAVRAS-CHAVE: Orquídea; aclimatização; simbiose.

Cycnoches haagii Barb. Rodr. is an epiphytic and not endemic orchid native to the Brazilian Savannah, and might also be found in the states of Amazonas, Pará, Rondônia, Goiás and Mato Grosso, in vegetation formations such as ciliary forest, palm grove and vegetation on rocky outcrops (Rio de Janeiro 2018). In the Mato Grosso do Sul state, the

1. Received: Jun. 07, 2018. Accepted: Oct. 04, 2018. Published: Dec. 19, 2018. DOI: 10.1590/1983-40632018v4853396.

2. Universidade Federal de Mato Grosso do Sul, Campus de Chapadão do Sul, Chapadão do Sul, MS, Brasil.

E-mail/ORCID: mateus-torrezan@hotmail.com/0000-0002-8474-6904, daly.padilha@ufms.br/0000-0001-6511-3362, manoela.avs@hotmail.com/0000-0002-7137-7601.

3. Universidade Federal do Vale do São Francisco, Campus de Ciências Agrárias, Colegiado de Engenharia Agronômica, Petrolina, PE, Brasil.E-mail/ORCID: vespasiano.paiva@univasf.edu.br/0000-0003-3347-7043, alanajsilva@gmail.com/ 0000-0001-9725-9120. 
species was reported in the municipality of Costa Rica (Barros et al. 2018).

Our observations have shown that $C$. haagii has been found in a low frequency, always preferring the Attalea phalerata Mart. Ex Spreng. palm as phorophyte. For being a species with a high ornamental potential, studies on the propagation processes of this orchid are essential, not only to improve the production process, making it economically viable, but also for preservation, promoting the perpetuation of the species, and thus reducing the risk of extinction.

In this century, the most rapid growth in the human population with the greatest contingent pressure on natural resources has occurred in regions where biological diversity is high (Kennedy 2006). In addition, the fragmentation of habitats, removal of key species critical to the continued existence of ecosystems, increased susceptibility to fire threats and pollinators decline are also documented to result in drastic losses in orchid populations and diversity (Sosa \& Platas 1998, Coates \& Dixon 2007). In this way, there is an urgent need for a differentiated policy to guide cultivation operations based on the biological characteristics, cultural significance, market demands and conservation status of the target species (Liu et al. 2018).

The in vitro propagation has proven to be effective in the mass propagation of a number of endangered orchid species, or with a high commercial value (Soares et al. 2012). According to Rasmussen et al. (2015), in any conservation or restoration program for orchid populations, a delimitation of factors that limit seed germination and seedling establishment must be investigated.

Orchids produce vast numbers of tiny seeds lacking storage reserves, such as the endosperm (Arditti \& Ghani 2000, Batty et al. 2000, Yang \& Lee 2014). The production of great numbers of small seeds supports high dispersal rates (Batty et al. 2002, Zettleret al. 2003), seen that few seeds germinate, and even fewer develop into mature plants in nature (Swarts \& Dixon 2009), because, under natural conditions, seeds of most of the epiphytical orchid species shall germinate only in association with a compatible mycorrhizal fungus, due to limited food reserves (Ramsay et al. 1986, Arditti et al. 1990). Therefore, orchid seeds have a complete dependency on nutrients supplied by the mycorrhizal association during early germination and seedling establishment phases (Rasmussen 1995), due to an impaired ability of the seeds to metabolize polysaccharides and lipids (Manning \& Van Staden 1987).

This fungal-orchid symbiotic process is predominantly characterized by the development of fungal compositions within cells, called pelotons, which develop inside the parenchyma cells of the root cortex (Peterson et al. 2004). This, however, is a mutualistic relationship, in which there is carbon flow flux in both directions (Cameron \& Leake 2006). Therefore, the use of mycorrhizal fungi from germination aims to improve the growth and development of the seedlings, even in cases in which in vitro germination does not require the presence of the symbiotic process to occur, in order to ensure greater future gains during the acclimatization phase (Wang et al. 211, Dan et al. 2012). The use of MS (Murashige \& Skoog 1962), a traditional medium to symbiotic orchids seedling development, was related by Wang et al. (2013) in the symbiotic cultivation of Dendrobium officinale Kimura et Migo and, according to Bocayuva et al. (2014), the addition of macro and micronutrients to the OMA medium provides the production of more developed Hadrolaelia jongheana (Rchb.f.) Chiron \& V. P. Castro plants, without inhibiting the mycorrhizal growth in ten months, resulting in an efficient and faster protocol to conduct the later stages of acclimatization and in situ reintroduction for species conservation.

The symbiotic or asymbiotic in vitro propagation of $C$. haagii is required to guide management strategies for the successful conservation of the species. Thus, this study aimed to develop a complete seminal propagation protocol of $C$. haagii, as well as to verify the influence of the mycorrhizal fungus presence in the germination phase and in the posterior development of the in vitro seedlings.

\section{MATERIAL AND METHODS}

For the conduction of the experiments, a mature capsule was obtained from a $C$. haagii adult palm tree known as acuri (Attalea phalerata Mart. Ex Spreng.), in the pasture area of a farm $\left(18^{\circ} 32\right.$ ' $25.52^{\prime \prime} \mathrm{S}$ and $53^{\circ} 9^{\prime} 27.03$ 'W) near the municipality of Costa Rica, Mato Grosso do Sul state, Brazil, in September 2015. The capsule was carefully collected in accordance with the SISBIO 22570-2 authorization. For species identification procedures, the exsiccate of a flowering plant was prepared and deposited in the herbarium of the Botanical Institute, in São Paulo. 
The experiment consisted of nine treatments with culture media $\left[4 \mathrm{~g} \mathrm{~L}^{-1}\right.$ of oat meal and $7 \mathrm{~g} \mathrm{~L}^{-1}$ of agar $\left(\mathrm{HiMedia}^{\circledR}\right)$, KNUDSON C (Knudson salts + $20 \mathrm{~g} \mathrm{~L}^{-1}$ of sucrose $+7 \mathrm{~g} \mathrm{~L}^{-1}$ of agar) and $\mathrm{B} \& \mathrm{G}\left(47 \mathrm{~g} \mathrm{~L}^{-1}\right.$ of salt $+7 \mathrm{~g} \mathrm{~L}^{-1}$ of agar)], with the $\mathrm{pH}$ adjusted to 5.6 before the autoclaving process at $121^{\circ} \mathrm{C}$ and $104 \mathrm{KPa}$, for $20 \mathrm{~min}$. After autoclaving, two mycorrhizal fungi belonging to the Tulasnella genus [FCH - isolated from roots of the terrestrial orchid Cyrtopodium paludicolum Hoehne LC; and FHC3E - isolated from the roots of the rupicola orchid Hoffmannseggella caulescens (Lindl.) H. G. Jones] were inoculated in the asymbiotic and symbiotic treatments.

In the symbiotic treatment, a disc of $5 \mathrm{~mm}$ of potato:dextrose:agar (PDA) medium containing the mycorrhizal fungus was present in the sowing medium. In a laminar flow hood, prior to sowing, seeds were disinfested through soaking in autoclaved distilled water for $15 \mathrm{~min}$, drained and added with a solution of sodium hypochlorite $(0.66 \%$ of active chlorine), for $10 \mathrm{~min}$. They were washed (three times) in autoclaved distilled water and sowed into Petri dishes (9 cm in diameter) containing $50 \mathrm{~mL}$ of asymbiotic or symbiotic culture medium, as previous described. After the inoculation of seeds, the Petri dishes were taken to the plant growth room, with a 16-h photoperiod, irradiation of $36 \mu \mathrm{mol} \mathrm{m} \mathrm{m}^{-2} \mathrm{~s}^{-1}$ provided by tubular led lamps (Philips, Ledtube $18 \mathrm{~W}$ - white) and temperature of $27 \pm 2{ }^{\circ} \mathrm{C}$, where they remained for 90 days. Following that, the evaluation of the germination percentage was performed by counting the number of germinated and not germinated seeds in three sample fields $(2 \mathrm{~cm}$ in diameter) of each replicate (Petri dish), using a stereo microscope (Paiva Neto et al. 2015). The seeds were considered germinated when the embryo became swollen and chlorophyllous, according to Bektas et al. (2013), and used to calculate the germination rate.

The experiment was conducted in a $3 \times 3$ factorial scheme, with three cultivation media (OMA, B\&G and Knudson) combined with a mycorrhizal fungus factor (asymbiotic, isolated $\mathrm{FCH}$ and isolated FHC3E), totalizing nine treatments, each with four replicates (Petri dishes).

The protocorms obtained through the four best treatments $(\mathrm{OMA}+\mathrm{FHC} 3 \mathrm{E}, \mathrm{B} \& \mathrm{G}, \mathrm{B} \& \mathrm{G}+\mathrm{FCH}$ and $\mathrm{B} \& \mathrm{G}+\mathrm{FHC} 3 \mathrm{E})$, concerning the germination rate, were transferred to $250 \mathrm{~mL}$ containers with $50 \mathrm{~mL}$ of culture medium without fungal re-inoculation. In this way, this new experiment consisted of four treatments with 10 replicates (flasks), with 10 protocorms per container. The period of protocorms development was of 120 days when the following evaluations were performed: number of leaves, shoot size $(\mathrm{cm})$, number of roots, largest root size $(\mathrm{cm})$ and total fresh matter $(\mathrm{g})$.

To check the fungus presence in the seedlings, before the acclimatization phase, roots were collected and transversal sections were manually cut with a razor blade, and then observed using a light microscope coupled with a digital camera.

For the acclimatization experiment, 15 seedlings per treatment were used, originated from a previous in vitro experiment, being each seedling considered as one replicate. The seedlings were planted in plastic vessels $\left(120 \mathrm{~cm}^{3}\right)$ containing the commercial substrate Basaplant-Ornamentais ${ }^{\circledR}$ (Base Agro) and no carbonized rice husk, in equal volume proportions. The plastic vessels were randomly distributed in a greenhouse with $50 \%$ of shading through transparent film and Aluminet shade cloth (Ginegar Polysack), and equipped with an intermittent irrigation system comprised of microsprinklers activated by an automatic timer system, with two daily irrigation cycles of $2 \mathrm{~min}$ each, resulting in approximately $0.62 \mathrm{~mm}$ day $^{-1}$. The period for the acclimatization phase was of 90 days, when the survival rates of the seedlings were measured.

The plants were kept under the same conditions described for acclimatization and visually observed at 12 and 24 months after the transplantation to acclimatization, to verify the flowering occurrence. In the sixth month of cultivation, the plants were transplanted to larger plastic vessels $\left(625 \mathrm{~cm}^{3}\right)$ with addition of the same substrate.

The experimental design was completely randomized for all experiments. If necessary, an arcsine square root transformation was performed. After that, data were submitted to analysis of variance (Anova) and averages compared by the Tukey test at $5 \%$ of significance $(\mathrm{p}<0.05)$, using the Sisvar 4.3 statistical software (Ferreira 2014).

\section{RESULTS AND DISCUSSION}

Both the tested factors, presence of the fungus and culture medium, showed a significant effect on the germination process, interfering in the seed percentage that was converted into protocorms, and with interaction between the two factors. In 
the germination of $C$. haagii (Table 1), the highest percentages of germinated seeds were obtained in the OMA medium combined with FHC3E (OMA + FHC3E), B\&G + FHC, B\&G + FHC3E and asymbiotic $B \& G$, all these with germination values over $60 \%$. The values obtained for the best treatments are higher than those described by Carvalho et al. (2018), who evaluated the percentage of in vitro symbiotic germination for the C.paludicolum orchid in association with mycorrhizal fungi, collected in the same geographic region, reaching $52.89 \%$ of maximum germination.

The B\&G medium provided the best performance for the percentage of asymbiotically germinated seeds $(78.4 \%)$, if compared to OMA $(12.65 \%)$ and Knudson (41.54 \%). For the symbiotic cultivation, although the $\mathrm{B} \& \mathrm{G}$ medium resulted in germination percentages of $71.35 \%$ and $61.55 \%$, when combined with the FCH and FHC3E fungi, respectively, the best germinative percentage, numerically, occurred in the combination of the OMA medium with the FHC3E fungus $(82.17 \%)$, although no statistical difference was detected. The addition of fungal isolates to the B\&G medium did not contribute to increase the germination percentage, since the medium itself was efficient in the embryo nutrition, making the fungal presence unnecessary to this phase.

The asymbiotic OMA medium resulted in the lowest germination percentage $(12.65 \%)$. On the other hand, the highest percentage $(82.17 \%)$ of C. haagii was obtained when OMA was inoculated with FHC3E. The asymbiotic OMA medium does not provide sufficient nutrient requirements to the seeds, since the presence of the FCH $(\mathrm{OMA}+\mathrm{FCH})$ and FHC3E (OMA + FHC3E) isolates resulted in respective increases of $649.6 \%$ and $265.6 \%$ in the

Table 1. In vitro asymbiotic and symbiotic germination percentages of Cycnoches haagii seeds, at 90 days after the inoculation in culture media.

\begin{tabular}{lccc}
\hline \multirow{2}{*}{ Culture media } & \multirow{2}{*}{ Asymbiotic } & \multicolumn{2}{c}{ Mycorrhizal fungi } \\
\cline { 3 - 4 } & & FCH & FHC3E \\
\hline OMA & $12.65 \mathrm{cC}$ & $46.25 \mathrm{bB}$ & $82.17 \mathrm{aA}$ \\
KNUDSON & $41.45 \mathrm{bAB}$ & $50.25 \mathrm{bA}$ & $24.57 \mathrm{cB}$ \\
B\&G & $78.40 \mathrm{aA}$ & $71.35 \mathrm{aA}$ & $61.55 \mathrm{bA}$ \\
\hline
\end{tabular}

Data subjected to the analysis of variance and Tukey test at $5 \%$ of significance, obtained after an arcsine square root-transformation of the proportions. Averages followed by the same lowercase letters in the column and uppercase letters in the row are not statistically different by the Tukey test $(\mathrm{p}<0.05)$. number of total germinated seeds, when compared to the OMA-asymbiotic treatment. In this regard, FHC3E was more efficient than FCH, when the germination medium had more complex sources of carbohydrates (OMA), such as starch, considering that its composition is oat-based. Mycorrhizal fungi were able to induce the degradation of the polysaccharides present in the medium for later availability for the seeds. However, the combination of FCH and OMA was less efficient.

The addition of the fungal isolates to the Knudson medium did not result in significant gains in the germinative percentages (Table 1). This is probably due to the fact that this medium offers a greater contribution of monosaccharides and disaccharides to the seeds and fungi, and, as a consequence, it is not a recommended medium for the co-cultivation of the FHC3E isolate and the orchid embryo, resulting in a reduction of $59.3 \%$ in the total germinated seeds, in relation to the Knudson-asymbiotic medium. Originally, the Knudson medium was proposed for the in vitro germination of orchid seeds (Knudson 1946), and it has been considered a medium with lower ionic concentration, when compared, for example, to the MS medium (Melo et al. 2015). It was noted by Kozai \& Kubota (2005) that the water potential of the MS medium (-0.212 MPa) is three times lower than that of Knudson (0.069 MPa). Thus, Knudson was an unfavorable medium to $C$. haagii embryo and FHC3E symbiotic establishment, despite the fungus growth.

The seedlings resulting from the development of protocorms originated from the $\mathrm{B} \& \mathrm{G}$ medium, regardless of the asymbiotic or symbiotic condition, presented superiority in all the evaluated growth parameters (Table 2), when compared with the seedlings originated from the other media. However, root and shoot lengths and total fresh matter of the seedlings (Table 2) indicate a superior development of the protocorm originated and established in the $\mathrm{B} \& \mathrm{G}$ medium, in the asymbiotic and symbiotic conditions with the FCH fungus (Table 2). On the other hand, the worst performance for all the analyzed parameters, except for root length, was obtained by the seedlings from the OMA + FCH3E medium, which, despite providing the highest germination percentage, did not present the same efficiency in the development of seedlings.

The total fresh matter accumulation also presented prominence for seedlings cultivated in 
the $\mathrm{B} \& \mathrm{G}$ medium alone or associated with the $\mathrm{FCH}$ fungus, which presented $2.05 \mathrm{~g}$, differing statistically from the other treatments (Table 2; Figure 1A). The lowest total fresh matter average was observed for seedlings from OMA associated with FHC3E with only $0.19 \mathrm{~g}$ (Table 2; Figure 1A). These results evidenced the great importance in the choice of the culture medium, demonstrating that, even when the symbiotic association between the fungus and the plant occurs, the availability of medium constituents for plant material is medium-dependent. This medium importance is more evident when the morphological growth of the seedlings is compared (Figure 1A). In this context, it was verified that not all the colonization by the mycorrhizal fungi resulted in immediate gain for the seedlings or in all its stages of development. Therefore, the obtained results, to a certain extent, contradict the proposition of Yoder (2000) and Chang (2007), who consider that symbiotically germinated seedlings generally have advantages, if compared to those germinated asymbiotically, considering the greater absorption capacity of water and nutrients. This fact was not confirmed under in vitro conditions, when seeds were sown in media containing ionic nutrients and accessible carbohydrates. However, Yoder (2000) and Chang (2007) affirm that gains may occur in later stages of plant development, making them more resistant, mainly to adverse environmental conditions, as it occurs here in the acclimatization phase, when superior growth and development were observed in seedlings cultivated symbiotically in the $B \& G$ medium, comparing with asymbiotic seedlings of the same medium.

Some fungal isolates have a greater competence in promoting the symbiotic development of orchids than others, suggesting that, for the use of mycorrhizal fungi in the symbiotic production of orchid seedlings, it is essential to test them for promoting both the germination and development of the species under study, since there is a variation in this efficiency

Table 2. In vitro growth parameters, number of leaves and roots, shoot and root length, and total fresh matter of Cycnoches haagii seedlings after 90 days on OMA and B\&G media, developed from protocorms originated from asymbiotic and symbiotic germination media with two mycorrhizal fungi belonging to the Tulasnella genus (FCH and FHC3E); and ex vitro survival percentage in the acclimatization phase after 120 days, under greenhouse conditions.

\begin{tabular}{|c|c|c|c|c|c|c|}
\hline \multirow{2}{*}{ Culture media } & \multicolumn{2}{|c|}{ Number } & \multicolumn{2}{|c|}{ Length $(\mathrm{cm})$} & \multirow{2}{*}{ Fresh matter $\left(\mathrm{g} \mathrm{plant}^{-1}\right)$} & \multirow{2}{*}{ Survival (\%) } \\
\hline & Leaf & Root & Shoot & Root & & \\
\hline $\mathrm{B} \& \mathrm{G}$ & $5.93 \mathrm{a}$ & $8.63 \mathrm{a}$ & $6.03 \mathrm{a}$ & $4.42 \mathrm{a}$ & $1.47 \mathrm{ab}$ & $100 \mathrm{a}$ \\
\hline $\mathrm{B} \& \mathrm{G}+\mathrm{FCH}$ & $6.07 \mathrm{a}$ & $9.63 \mathrm{a}$ & $6.60 \mathrm{a}$ & $4.27 \mathrm{a}$ & $2.05 \mathrm{a}$ & $100 \mathrm{a}$ \\
\hline $\mathrm{B} \& \mathrm{G}+\mathrm{FHC} 3 \mathrm{E}$ & $5.33 \mathrm{ab}$ & $7.70 \mathrm{a}$ & $4.33 \mathrm{~b}$ & $2.03 \mathrm{~b}$ & $0.75 \mathrm{bc}$ & $100 \mathrm{a}$ \\
\hline $\mathrm{OMA}+\mathrm{FHC} 3 \mathrm{E}$ & $4.10 \mathrm{~b}$ & $3.30 \mathrm{~b}$ & $2.08 \mathrm{c}$ & $3.26 \mathrm{ab}$ & $0.19 \mathrm{c}$ & $40 \mathrm{~b}$ \\
\hline $\mathrm{CV}(\%)$ & 16.04 & 18.91 & 15.33 & 18.55 & 23.22 & 7.22 \\
\hline
\end{tabular}

Averages followed by the same letters in the column are statistically equal within each other, according to the Tukey test at $5 \%$ of significance.

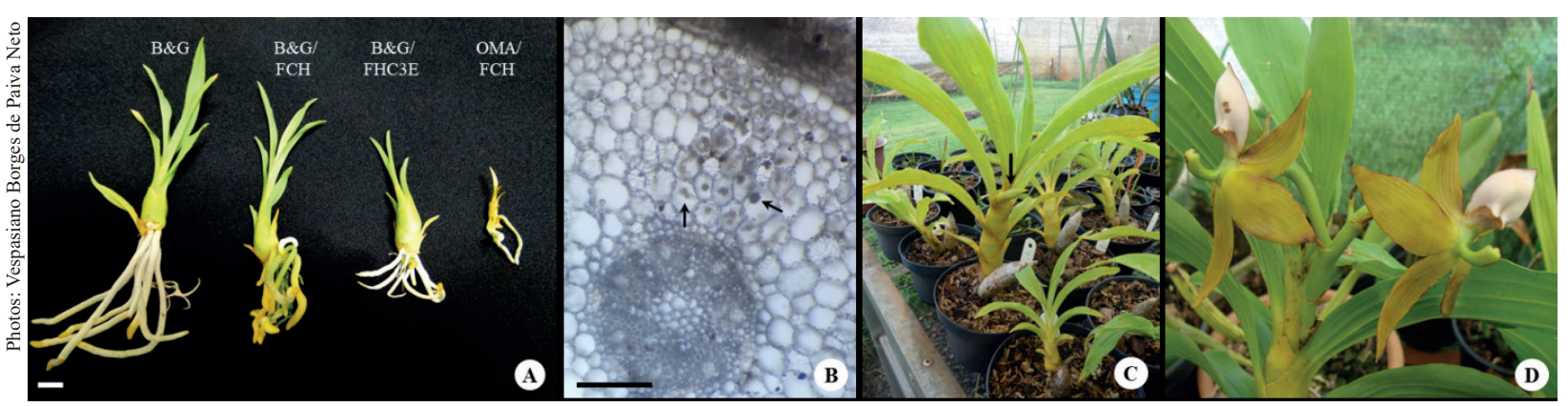

Figure 1. Cycnoches haagii seedlings originated from symbiotic and asymbiotic germination in vitro. A: seedlings at the final development phase preceding the acclimatization phase $(\mathrm{bar}=1 \mathrm{~cm})$; B: root transverse section of $C$. haagii seedlings originated from the $\mathrm{B} \& \mathrm{G}$ medium associated with the $\mathrm{FCH}$ fungus, showing the pelotons presence (arrows) in the cortical cells (bar $=200 \mu \mathrm{m}$ ); : seedlings of $C$. haagii originated from the B\&G medium associated with the FCH isolate at 24 months after the beginning of acclimatization, showing the presence of floral buds (arrow); D: details of a female flower of the C. haagii plant. 
between fungi of the same species and among fungi of different species of a genus (Otero et al. 2005, Pereira et al. 2011).

A relevant factor for $\mathrm{FCH}$, in relation to the FHC3E total fresh matter, might be the fact that $\mathrm{FCH}$ was isolated from an orchid species found in the same geographical region of $C$. haagii, whereas the FHC3E isolate was obtained of a native species from the Minas Gerais state. Additionally, in taxonomic aspects, the Cycnoches genus is closer to the Cyrtopodium genus than to Laelia. In this respect, in some orchid species, the mycorrhizal fungi promotes a more efficient seed germination and seedling development in populations originated close to where the sample was collected (Otero et al. 2005, Stewart \& Kane 2006, Pereira et al. 2011).

Light microscopy analysis of root sections showed the pelotons presence in the cortical parenchyma cells of all symbiotic seedlings (Figure 1B) and absence in asymbiotic ones. In this way, we can affirm that $\mathrm{FCH}$ and $\mathrm{FHC} 3 \mathrm{E}$ were efficient in the colonization of $C$. haagii seedling roots.

In the acclimatization phase, the plants which obtained the highest survival rate were those from the $B \& G$ culture medium, independently of the fungal association, reaching $100 \%$ of survival, and the lowest acclimatization performance was obtained by the seedlings grown in the OMA medium added with the isolate FHC3E, with only $40 \%$ of survival (Table 1).

These results demonstrate that, although the FHC3E isolate presents an excellent contribution in the germination phase, that does not repeat in the developmental and acclimatization phases. Therefore, it is not possible to state that the mycorrhizal fungi present in the germination phase, when the fungal association is obligatory in nature, are necessarily the same as those found in adult plants, when the association may be optional (Porras-Alfaro \& Bayman 2007). So, there are specific fungi for each stage of development of the orchid life cycle (Shimura et al. 2009). More recently, experimental observations with the Oeceoclades maculata (Lindl.) Lindl. orchid allowed to affirm that, in some cases, there could be a high specificity for fungi during the seed germination, but unusually promiscuous in adult plants (Bayman et al. 2016). This result is in agreement with our observation regarding differences in fungi type for each development phase.
It should be noted here that the plants from the $\mathrm{B} \& \mathrm{G}$ medium associated with the $\mathrm{FCH}$ fungus presented a clear reproductive precocity, with $40 \%$ of the acclimatized plants showing inflorescences at 12 months after the beginning of the abovementioned process. This phenomenon also occurred in the second year, when $60 \%$ of the plants flowered again (Figures $1 C$ and 1D). In this second year, $30 \%$ of the plants from the $\mathrm{B} \& \mathrm{G}$ treatment associated with the FHC3E isolate also flowered. Plants of the remaining treatments continued in the vegetative stage. Hoang et al. (2017) reported a similar flowering phenomenon in some plants from ghost orchid (Dendrophylax lindenii), after two years of in vitro germination on symbiotic conditions. Indeed, we are convinced that this reproductive precocity is a consequence of the benefits of the orchid-mycorrhizal symbiosis, allowing an increase in plant growth and development.

The symbiotic germination makes it possible to obtain robust seedlings for the reintroduction in the natural environment (Zettler et al. 2007), and the mycorrhization of seedlings provides a greater absorption of nutrients and protection of biotic and abiotic stresses during the acclimatization or reintroduction stages to the natural environment (Dearnaley et al. 2012, Aewsakul et al. 2013).

It is clear that, for the use of mycorrhizal fungi in the seedling production, it is important to test them for the efficiency in promoting the germination and development of the orchids (Rasmussen 2002, Stewart \& Kane 2006), since changes in this efficiency might be observed among isolates of the same species and among isolates of different species of a genus. In this context, an associated fungus can promote a great contribution only in a specific plant development phase, and little or no contribution at all in other phases (Herrera et al. 2017). Here we found that, despite the $\mathrm{FCH}$ presence in the traditional asymbiotic media, it did not contribute effectively during the in vitro development phases, as germination and seedling growth, but it provided a representative effect in the ex vitro development phase of $C$. haagii seedlings.

\section{CONCLUSION}

The $\mathrm{B} \& \mathrm{G}$ medium, associated with the Tulasnella sp. (FCH) mycorrhizal fungus, is adequate for in vitro germination and seedlings 
growth of Cycnoches haagii, resulting in the best plantlet development and acclimatization, including precocious flowering.

\section{ACKNOWLEDGMENTS}

The authors thank the Fundação de Apoio ao Desenvolvimento do Ensino, Ciência e Tecnologia do Estado de Mato Grosso do Sul (Fundect) and Conselho Nacional de Desenvolvimento Científico e Tecnológico (CNPq), for financial support.

\section{REFERENCES}

AEWSAKUL, N. et al. Ex vitro symbiotic germination of Spathoglotis plicata blume on common orchid cultivation substrates. Scientia Horticulturae, v. 160, n. 1, p. 238-242, 2013.

ARDITTI, J. et al. The contribution of orchid mycorrhizal fungi to seed germination: a speculative review. Lindleyana, v. 5, n. 4, p. 249-255, 1990.

ARDITTI, J.; GHANI, A. K. A. Tansley review no. 110: numerical and physical properties of orchid seeds and their biological implications. New Phytologist, v. 145, n. 3, p. 367-421, 2000.

BARROS, F. et al. Checklist das Orchidaceae do estado de Mato Grosso do Sul, Brazil. Iheringia, v. 73, suppl., p. 287-296, 2018.

BATTY, A. L. et al. Orchid conservation and mycorrhizal associations: microorganisms in plant conservation and biodiversity. Dordrecht: Kluwer Academic Publishers, 2002.

BATTY, A. L. et al. Soil seed bank dynamics of terrestrial orchids. Lindleyana, v. 15, n. 4, p. 227-236, 2000.

BAYMAN, P. et al. Age-dependent mycorrhizal specificity in an invasive orchid, Oeceocla desmaculata. American Journal of Botany, v. 103, n. 11, p. 1880-1889, 2016.

BEKTAS, E. et al. In vitro germination, protocorm formation, and plantlet development of Orchis coriophora (Orchidaceae), a naturally growing orchid species in Turkey. Turkish Journal of Botany, v. 37, n. 2, p. 336342, 2013.

BOCAYUVA, M. F. et al. O efeito de micro e macro nutrientes na micorrização e desenvolvimento de plântulas micorrizadas de Hadrolaelia jongheana (Orchidaceae). 2014. Available at: <http:// eventosolos.org.br/fertbio2014/ anais/arquivos_anais/890.Image.Marked.pdf $>$. Access on: 15 Feb. 2018.
CAMERON, D. D.; LEAKE, J. R. Mutualistic mycorrhiza in orchids: evidence from plant-fungus carbon and nitrogen transfers in the green-leaved terrestrial orchid Goodyera repens. New Phytologist, v. 171, n. 2, p. 405416, 2006.

CARVALHO, O. C. et al. Cyrtopodium paludicolum germination with two Tulasnella isolates. Acta Botanica Brasilica, v. 32, n. 1, p. 107-112, 2018.

CHANG, D. C. N. The screening of orchid mycorrhizal fungi (OMF) and their applications. In: CHEN, W. H.; CHEN, H. H. (Eds.). Orchid biotechnology. Singapore: World Scientific, 2007. p. 77-98.

CHASE, M. W. et al. An updated classification of Orchidaceae. Botanical Journal of the Linnean Society, v. 177, n. 2, p. 151-174, 2015.

COATES, D. J.; DIXON, K. W. Current perspectives in plant conservation biology. Australian Journal of Botany, v. 55, n. 3, p. 187-193, 2007.

DAN, Y.; MENG, Z. X.; GUO, S. X. Effects of forty strains of Orchidaceae mycorrhizal fungi on growth of protocorms and plantlets of Dendrobium candidum and D. nobile. African Journal of Microbiology Research, v. 6, n. 1, p. 34-39, 2012.

DEARNALEY, J. D. W. et al. Orchid mycorrhizas: molecular ecology, physiology, evolution and conservation aspects. In: HOCK, B. (Ed.). The Mycota IX: fungal associations. 2. ed. Berlin: Springer, 2012. p. 207-230.

FERREIRA, D. F. Sisvar: a guide for its bootstrap procedures in multiple comparisons. Ciência e Agrotecnologia, v. 38, n. 2, p. 109-112, 2014.

HERRERA, H. et al. Mycorrhizal compatibility and symbiotic seed germination of orchids from the Coastal Range and Andes in south central Chile. Mycorrhiza, v. 27, n. 3, p. 175-188, 2017.

HOANG, N. H. et al. Comparative seed germination and seedling development of the ghost orchid, Dendrophylax lindenii (Orchidaceae), and molecular identification of its mycorrhizal fungus from south Florida. Annals of Botany, v. 119, n. 3, p. 379-393, 2017.

HOSSAIN, M. M.; SHARMA, M.; PATHAK, P. In vitro propagation of Dendrobium aphyllum (Orchidaceae): seed germination to flowering. Journal of Plant Biochemistry and Biotechnology, v. 22, n. 2, p. 157-167, 2013.

HUANG, H. et al. Host-specificity of symbiotic mycorrhizal fungi for enhancing seed germination, protocorm formation and seedling development of overcollected medicinal orchid, Dendrobium devonianum. Journal of Microbiology, v. 56, n. 1, p. 42-48, 2018. 
KENNEDY, D. Life on a human dominated planet: state of the planet 2006-2007. Washington, DC: Island Press, 2006.

KNUDSON, L. A new solution for germination of orchid seeds. American Orchid Society Bulletin, v. 15, n. 9, p. 214-217, 1946.

KOZAI, T.; KUBOTA, C. In vitro root zone environments and their effects on growth and development of plants. In: KOZAI, T. et al. Photoautotrophic (sugar-free medium) micropropagation as a new micropropagation and transplant production system. Dordrecht: Springer, 2005. p. 53-60.

LIU, H. et al. Conservation impacts of commercial cultivation of endangered and overharvested plants. 2018. Available at: <https://onlinelibrary.wiley.com/doi/ epdf/10.1111/cobi.13216>. Access on: 10 Oct. 2018.

MANNING, J. C.; VAN STADEN, J. The development and mobilization of seed reserves in some African orchids. Australian Journal of Botany, v. 35, n. 3, p. 343-353, 1987.

MELO, G. M. et al. Asymbiotic germination of the genus Cattleya in different nutritive media. Plant Cell Culture and Micropropagation, v. 11, n. 1, p. 19-26, 2015.

MURASHIGE, T.; SKOOG, F. A revised medium for rapid growth and bioassays with tobacco tissue cultures. Physiologia Plantarum, v. 15, n. 3, p. 473-497, 1962.

OTERO, J. T. et al. Variation in mycorrhizal performance in the epiphytic orchid Tolumnia variegate in vitro: the potential for natural selection. Evolutionary Ecology, v. 19, n. 1, p. 29-43, 2005.

PAIVANETO, V. B. et al. The Bletia catenulata ornamental orchid is self-compatible but pollinator-dependent for reproduction. Pesquisa Agropecuária Tropical, v. 45, n. 4, p. 473-479, 2015.

PEREIRA, M. C. et al. Germinação de sementes e desenvolvimento de protocormos de Epidendrum secundum Jacq. (Orchidaceae) em associação com fungos micorrízicos do gênero Epulorhiza. Acta Botanica Brasilica, v. 25, n. 3, p. 534-541, 2011.

PETERSON, R. L. et al. Mycorrhizas: anatomy and cell biology. Ottawa: NRC Research Press, 2004.

PORRAS-ALFAROS, A.; BAYMAN, P. Mycorrhizal fungi of Vanilla: diversity, specificity and effects on seed germination and plant growth. Mycologia, v. 99, n. 4, p. 510-525, 2007.

RASMUSSEN, H. N. et al. Germination and seedling establishment in orchids: a complex of requirements. Annals of Botany, v. 116, n. 3, p. 391-402, 2015.

RASMUSSEN, H. N. Recent developments in the study of orchid mycorrhiza. Plant and Soil, v. 244, n. 1-2, p. 149163, 2002.
RASMUSSEN, H. N. Terrestrial orchid: from seed to mycotrophic plant. Cambridge: Cambridge University Press, 1995.

RIO DE JANEIRO. Jardim Botânico. Flora do Brasil 2020. 2018. Available at: <http://floradobrasil.jbrj.gov. br/>. Access on: 03 Dec. 2018.

SHIMURA, H. et al. Characterization of mycorrhizal fungi isolated from the threatened Cypripedium macranthos in a northern island of Japan: two phylogenetically distinct fungi associated with the orchid. Mycorrhiza, v. 19, n. 8, p. 525-534, 2009.

SOARES, J. S. et al. Germinação assimbiótica e desenvolvimento de Dendrobium nobile Lindl. sob efeito de reguladores vegetais no tratamento pré-germinativo. Revista Brasileira de Plantas Medicinais, v. 14, n. 4, p. 617-623, 2012.

SOSA, V.; PLATAS, T. Extinction and persistence of rare orchids in Veracruz, Mexico. Conservation Biology, v. 12, n. 2, p. 451-455, 1998.

STEWART, S. S.; KANE, M. E. Symbiotic seed germination of Habenaria macroceratitis (Orchidaceae), a rare Florida terrestrial orchid. Plant Cell Tissues and Organ Culture, v. 86, n. 2, p. 159-167, 2006.

SWARTS, N. D.; DIXON, K. W. Terrestrial orchid conservation in the age of extinction. Annals of Botany, v. 104, n. 3, p. 543-556, 2009.

WANG, H. et al. In situ seed baiting techniques in Dendrobium officinale Kimuraet Migo and Dendrobium nobile Lindl.: the endangered Chinese endemic Dendrobium (Orchidaceae). World Journal of Microbiology and Biotechnology, v. 27, n. 9, p. 2051-2059, 2011.

WANG, Q-X. et al. In vitro growth and carbon utilization of the green-leaved orchid Dendrobium officinale are promoted by mycorrhizal associations. Botanical Studies, v. 54, n. 23 , p. 1-9, 2013.

YANG, C-K.; LEE, Y-I. The seed development of a mycoheterotrophic orchid, Cyrtosia javanica Blume. Botanical Studies, v. 55, n. 44, p. 1-7, 2014.

YODER, J. A. Water requirements of terrestrial and epiphytic orchid seeds and seedlings, and evidence for water uptake by means of mycotrophy. Plant Science, v. 156, n. 2 , p. $145-150,2000$.

ZETTLER, L. W. et al. Conservation-driven propagation of an epiphytic orchid (Epidendrumnocturnum) with a mycorrhizal fungus. HortScience, v. 42, n. 1, p. 135-139, 2007.

ZETTLER, L. W. et al. Mycorrhizal diversity. In: DIXON, K. W. et al. (Eds.). Orchid conservation. Kota Kinabalu: Natural History Publications, 2003. p. 205-226. 